\title{
Data on the long-distance dispersal of Laxmann's shrew (Sorex caecutiens Laxmann, 1788) and the pygmy shrew (Sorex minutus Linnaeus, 1766)
}

Svetlana Mukhacheva ( $\nabla$ mukhacheva@mail.ru )

Institute of Plant and Animal Ecology RAS https://orcid.org/0000-0002-5114-4878

Oleg Tolkachev

Institute of Plant and Animal Ecology RAS

\section{Short Report}

Keywords: Shrews, long-distance movements, dispersal, rhodamine B

Posted Date: November 24th, 2021

DOI: https://doi.org/10.21203/rs.3.rs-1084688/v1

License: (c) (1) This work is licensed under a Creative Commons Attribution 4.0 International License.

Read Full License 


\section{Abstract}

We studied the long-distance dispersal of two species of shrews - Laxmann's shrew (Sorex caecutiens) and the pygmy shrew (Sorex minutus). Group marking with bait containing rhodamine B was used. These were the first data obtained on the long-distance movements of the pygmy shrew $(n=5)$, which extended from $475 \mathrm{~m}$ to $2570 \mathrm{~m}$ in a straight line. In the course of dispersion, Laxmann's shrews $(n=12)$ moved distances of up to $4500 \mathrm{~m}$, which is the maximum movement distance known for this species.

\section{Introduction}

Dispersal is defined as "circumstances in which individuals leave their existing home ranges and do not return" (Stenseth, Lidicker, 1992). This process can provide animals with several benefits, including empty patch colonization and avoidance of inbreeding (Bowler, Benton, 2005; Clobert et al., 2012). The main determinants of dispersal include the range of movements of the species and its ability to overcome various landscape discontinuities. Many species of small mammals, including murine rodents, are known to be able to travel distances of several kilometres (Allred, Beck, 1963; Clark et al., 1988; Dickman et al., 1995; Jung et al., 2005; Tolkachev, 2016a; Grigorkina, Olenev, 2018). For example, the maximum distance recorded for mouse-sized mammals is $14,730 \mathrm{~m}$ (Maier, 2002).

Animals of the family Soricidae are among the least studied species in this respect. There are only a few studies that include data on the long-distance movements of shrews (Michielsen, 1966 cit. on Tegelström, Hansson, 1987; Faust et al., 1971; Tegelström, Hansson, 1987; Bol'shakov, Bazhenov, 1988; Shchipanov et al., 2001; Shchipanov, 2007; Shchipanov, Pavlova, 2016). Laxmann's shrew (Sorex caecutiens Laxmann, 1788 ) and the pygmy shrew (Sorex minutus Linnaeus, 1766) are among the smallest extant mammalian species. Nevertheless, they have ranges that occupy a significant part of Eurasia (Zaitsev et al., 2014). Given their high reproductive rates and regular local extinctions in the winter, it is incredible that these animals maintain their species unity in such large areas. Long-range dispersal may be one of the key explanatory factors. However, there are very few data on the long-distance movement of Laxmann's shrews and none at all on pygmy shrews. This is primarily due to methodological difficulties in studying dispersal over long distances in small mammals (Bondrup-Nielsen, 1985; Stenseth, Lidicker, 1992; Sutherland et al., 2000; Nathan, 2001; Mohr et al., 2007).

One of the solutions to this problem is the use of group self-marking through bait. This technique allows for the automatic marking of a large number of animals living in or passing through a local area (marking plot) and focuses all efforts on catching marked individuals outside of the area (Lavoie et al., 1971; Szacki, Liro, 1991; Tolkachev, 2016 a, b, Grigorkina, Olenev, 2018;). Rhodamine B (RB) is a non-toxic dye that, when ingested with bait, binds to structures containing keratin, such as hair, vibrissae, and claws (Fisher, 1999). Thus, this biomarker can be successfully used for group marking of animals (Weerakoon et al., 2013; Cooney et al., 2015). The mark is detected by yellow fluorescence under green light. The retention time of the mark in the bodies of mammals is at least several months (up to 1 year). The 
possibility of marking shrews with RB was shown previously (Mohr et al., 2007; Tolkachev, 2019). Nevertheless, the long-distance movements of shrews have not been studied using this biomarker.

This paper presents the results of a study of the long-distance dispersal of $S$. caecutiens and S. minutus, which was carried out using group marking with rhodamine B.

\section{Materials And Methods}

The data presented in this work were obtained within the framework of a long-term (since 1990), ongoing study of small mammal communities inhabiting areas with different levels of industrial pollution (Mukhacheva, 2021; Mukhacheva, Sozontov, 2021). The investigated areas were located in fir-spruce forests near the Middle-Ural Copper Smelter (MUCS, $56^{\circ} 85^{\prime} \mathrm{N}, 59^{\circ} 90^{\prime} \mathrm{E}$ ).

To assess the long-distance dispersal of these animals, we used a group marking technique with rhodamine B (RB) in June-September 2018-2019. We prepared the bait based on oat flakes according to published guidelines (Tolkachev, Bespamyatnyh, 2019). The RB concentration was $800 \mathrm{mg} / \mathrm{kg}$ flakes. Before use, pieces of the bait were sprayed with unrefined sunflower oil. The experimental design included a marking plot where the RB bait was dispensed. The area of the marking plot was $1.5 \cdot 10^{4} \mathrm{~m}^{2}$ in 2018 and $4 \cdot 10^{4} \mathrm{~m}^{2}$ in 2019 (Fig. 1). The pieces of bait were distributed in the nodes of the $5 \times 5 \mathrm{~m}$ grid at a rate of $4 \mathrm{~kg}$ per $1 \cdot 10^{4} \mathrm{~m}^{2}$. As shown earlier, this protocol is quite effective (Tolkachev, 2019a). We repeated the marking in dry weather every 10-15 days during the summer (June 1 - August 30).

Three rounds of trapping of small mammals were carried out annually: in June (1st decade), July (2nd decade), and September (3rd decade). For a complete accounting of the animals, different types of traps located at different distances $(0-6 \mathrm{~km})$ from the marking plots were used. Fig. 1 shows only the test plots where shrews with RB marks were caught.

Wooden snap traps with hooks (Tolkachev, 2019b) were set in 6 test plots (3 lines in each plot per round). Each line consisted of 25 traps set at 5-7 m intervals and left open for four days with a daily check. The wooden live traps were set in 6 test plots ( 25 traps at $10 \mathrm{~m}$ intervals, set for three days, checked two times a day) during the 2 nd round. In addition, we examined shrews that were caught in Barber pitfall traps (15 traps in every test plot, in the nodes of each $10 \times 10 \mathrm{~m}$ grid) during parallel studies of terrestrial invertebrates (2nd round of 2018, 2 test plots; third round of 2019, 6 test plots). In 2019, two long transects were additionally established, including 100 and 170 traps (in an alternating sequence of 4:1 snap traps to live traps), spaced $10 \mathrm{~m}$ apart. The traps were set for four days with a single daily check. A total of 240 shrews of two species (S. caecutiens, S. minutus) were caught: 47 in snap traps, 21 in live traps, and 172 in Barber pitfall traps.

All captured animals were frozen and transported to the laboratory. The shrews were identified to the species level using appropriate identification keys based on exterior features (body weight and lengths of the body, tail, and hindfoot), condylobasal skull length, and toothrow structure. Unfortunately, animal 
dissection was not carried out due to the peculiarities of collecting and processing material from the Barber pitfall traps. Therefore, the sex of some animals was unknown.

RB marks were detected according to published procedures (Tolkachev, Bespamyatnyh, 2019; Tolkachev, 2019a). The range of distances at which the shrews with the RB marks could be detected was $0-4500 \mathrm{~m}$. To estimate the distance of the movement of individuals, the minimum distance (with an accuracy of 10 $\mathrm{m}$ ) from the point of capture to the nearest border of the marking plot was calculated. The calculation was carried out based on data from an eTrex 20 GPS receiver using detailed terrain maps.

\section{Results And Discussion}

\section{Laxmann's shrew}

Over two years, 158 S. caecutiens were captured, including 14 with an RB mark, 12 of which were found outside the marking plot (Table 1). The movement distances ranged from $80 \mathrm{~m}$ to $4500 \mathrm{~m}$ in a straight line. The movement occurred mainly within one forest area. Nevertheless, all animals had to cross at least one open area - a clearing approximately $20 \mathrm{~m}$ wide. Three shrews that covered the most significant distances (point 2, Fig. 1) crossed a river approximately $5 \mathrm{~m}$ wide. After that, they could move through the field and along the river's floodplain, which could potentially be a landscape conduit. In the literature, only one study was found describing the spontaneous movement of individuals of this species over long distances (Shchipanov et al., 2001). The maximum dispersal distance was $2500 \mathrm{~m}$ in that case. In our study, two animals were found at a distance of $4500 \mathrm{~m}$ from the edge of the marking plot. Group marking approach does not allow determining whether the animal had a home range before the start of the movement. Nevertheless, the considerable distance of the movement enabled us to confidently attribute it to dispersal. All the animals were immature, except for one female who moved $4150 \mathrm{~m}$.

\section{Pygmy shrew}

A total of 67 S. minutus were caught. Most of them were immature yearlings of both sexes. Only five individuals were marked. All of them were caught outside the marking plot (Table 1). An immature male showed the maximum movement, with a distance of $2570 \mathrm{~m}$. As in the case of $S$. caecutiens, all five individuals overcame landscape heterogeneity in the form of a clearing. We did not find data on the movements of individuals of this species outside of their home ranges in the literature. In test plots 4 and 7 , only marked animals were captured. If these samples adequately reflect the composition of the population, then points 4 and 7 are located in transit habitats without residents. These were the most unfavourable conditions for this species in terms of the surrounding plants and high levels of pollution of the territory, particularly the soil, forest litter, and food objects of the shrews (Vorobeichik, Kaigorodova, 2017; Bezel et al., 2013).

\section{Declarations}


Acknowledgements We are grateful to E.A. Belskaya and M.P. Zolotarev, who provided shrews from Barber pitfall traps, and to Yu.L. Sumorokov, E.Yu. Sumorokova, and S.Yu. Sumorokov for their help with the field studies.

\section{Compliance with ethical standards}

Conflicts of interest. The authors declare that they have no conflicts of interest.

Ethical approval. All applicable international, national, and institutional guidelines for the care and use of animals were followed. In the main experiment, a second marker was used for tagging rodents tetracycline, which forms a mark only in the growing bone structures of the body (mainly teeth) and cannot be used for marking shrews. In addition, for this study, it was necessary to determine the content of heavy metals in the organs and diet of the animals. The Bioethics Commission of the Institute of Plant and Animal Ecology, Ural Branch, RAS, approved the study (protocol №6 May 18, 2021).

Funding This study was performed within the framework of a state contract with the Institute of Plant and Animal Ecology, Ural Branch, Russian Academy of Sciences, and partly supported by the Russian Foundation for Basic Research, grant no. 20-04-00164a.

\section{References}

1. Allred D, Beck D (1963) Range of Movement and Dispersal of Some Rodents at the Nevada Atomic Test Site. J Mammal 44(2):190-200

2. Bezel VS, Mukhacheva SV (2013) Trophic levels of small mammals: multi-elemental composition and toxic load. Biol Bull 40(10):1-8

3. Bol'shakov VN, Bazhenov AV (1988) Radionuklidnye metody mecheniya v populyatsionnoi ekologii mlekopitayushcikh (Radionuclide Methods of Marking in Population Ecology of Mammals). Nauka, Moscow

4. Bondrup-Nielsen S (1985) An evaluation of the effects of space use and habitat patterns on dispersal in small mammals. Ann Zool Fennici 22:373-383

5. Bowler DE, Benton TG (2005) Causes and consequences of animal dispersal strategies: relating individual behavior to spatial dynamics. Biol Rev Camb Philos Soc 80:205-225

6. Clark BK, Kaufman DW, Kaufman GA, Finck EJ, Hand SS (1988) Long-distance movements by Reithrodontomys megalotis in tallgrass prairie. Am Midl Nat 120(2):276-281

7. Clobert J, Baguette M, Benton T, Bullock J, Ducatez S (2012) Dispersal ecology and evolution. Oxford University Press, Oxford

8. Cooney SA, Schauber EM, Hellgren EC (2015) Comparing permeability of matrix cover types for the marsh rice rat (Oryzomys palustris). Landscape Ecol 30:1307-1320

9. Dickman CR, Predavec M, Downey FJ (1995) Long-range movements of small mammals in arid Australia: implications for land management. J Arid Environ 31(4):441-452 
10. Faust BF, Smith MH, Wray WB (1971) Distances moved by small mammals as an apparent function of grid size. Acta Theriol 16(11):161-177

11. Fisher $P$ (1999) Review of using Rhodamine B as a marker for wildlife studies.Wild Soc Bull, 27:318329

12. Grigorkina EB, Olenev GV (2018) Migrations of rodents in the zone of local radioactive contamination at different phases of population dynamics and their consequences. Biol Bull 45(1):110-118

13. Jung TS, O'Donovan KS, Powell T (2005) Long-distance movement of a dispersing deer mouse, Peromyscus maniculatus, in the boreal forest. The Canadian field-naturalist 119(3):451-452

14. Lavoie GK, Atwell GC, Swink FN, Sumangil JP, Libay J (1971) Movement of the ricefield rat, Rattus rattus mundaneness, in response to flooding and plowing as shown by fluorescent bone labeling. Philippine agriculturist 54:325-330

15. Maier TJ (2002) Long-distance movements by female White-footed Mice, Peromyscus leucopus, in an extensive mixed-wood forest. Canadian Field-Naturalist 116(1):108-111

16. Michielsen NC (1966) Intraspecific and interspecific competition in the shrews Sorex araneus L. and S. minutus L. Arch Neerlandaises Zool 17:73-174

17. Mohr K, Leirs H, Katakweba A, Machang'u R (2007) Monitoring rodents' movements with a biomarker around introduction and feeding foci in an urban environment in Tanzania. African Zoology 42(2):294-298

18. Mukhacheva SV (2021) Long-term dynamics of small mammal communities in the period of reduction of copper smelter emissions: I. Composition, abundance, and diversity. Russ J Ecol 52(1):84-93. https: //doi.org/10.1134/S1067413621010100

19. Mukhacheva SV, Sozontov AN (2021) Long-term dynamics of small mammal communities in the period of reduction of copper smelter emissions: II. $\beta$-diversity. Russ. J. Ecol., 52(6): 532-541. https: //doi.org/10.1134/S1067413621060084

20. Nathan R (2001) The challenges of studying dispersal. Trends Ecol Evol 16(9):481-483

21. Shchipanov NA (2007) Understanding the boundaries between chromosome races of common shrews in terms of restricted movement by individual shrews. Russian J Theriol 6(1):117-122

22. Shchipanov NA, Pavlova SV (2016) Evolutionary and taxonomic differentiation of shrew species in the "Araneus" group of the genus Sorex. 2. Subdivision within the common shrew. Biology Bulletin 43:1087-1098

23. Shchipanov NA, Kalinin AA, Oleinichenko VYu, Demidova TB, Gontcharova OB (2001) Using of space by the shrew Sorex caecutiens (Insectivora, Mammalia). Home ranges and long-distance movements. Zoologicheskii Zhurnal, 80: 584-585

24. Stenseth NC, Lidicker WZJr (1992) Animal dispersal. Springer Science+Business Media, Dordrecht

25. Sutherland GD, Harestad AS, Price K, Lertzman KP (2000) Scaling of natal dispersal distances in terrestrial birds and mammals. Conserv Ecol 4(1):16. [online] URL: 
26. Szacki J, Liro A (1991) Movements of small mammals in the heterogeneous landscape. Landscape Ecol 5(4):219-224

27. Tegelström H, Hansson L (1987) Evidence of long distance dispersal in the Common shrew (Sorex araneus). Z Säugetierkunde 52:54-55

28. Tolkachev OV (2016a) A Study on the Migrations of Murine Rodents in Urban Environments. Russian Journal of Ecology 47(4):399-404

29. Tolkachev OV (2016b) The dispersal of the pygmy wood mouse (Sy/vaemus uralensis Pallas, 1811) and the bank vole (Clethrionomys glareolus Schreber, 1780) in fragmented landscapes. Contemporary Problems of Ecology 9:116-124

30. Tolkachev OV (2019a) A new baiting scheme and simple method of rhodamine B detection could improve the biomarking of small mammals. Eur J Wildl Res 65:10

31. Tolkachev OV (2019b) The etymology of some names of traps is applied in the studies of small mammals. Vestnik Tomskogo gosudarstvennogo universiteta. Biologiya $=$ Tomsk State University Journal of Biology 48:73-96

32. Tolkachev OV, Bespamyatnykh EN (2019) The new method of rhodamine mark detection and its application possibilities in zoological studies. J Sib Fed Univ Biol 12(4):352-365

33. Vorobeichik EL, Kaigorodova SY (2017) Long-term dynamics of heavy metals in the upper horizons of soils in the region of a copper smelter impacts during the period of reduced emission. Eurasian Soil Science 50(8):977-990

34. Weerakoon MK, Price CJ, Banks PB (2013) Hair type, intake, and detection method influence Rhodamine B detectability.J Wildl Manag, 77:306-312

35. Zaitsev MV, Voyta LL, Sheftel BI (2014) The mammals of Russia and adjacent territories. Lipotyphlans. Nauka, Saint Petersburg

\section{Tables}

Table 1. Discovered cases of long-distance movements of two species of shrews 


\begin{tabular}{|c|c|c|c|c|c|}
\hline \multirow[t]{2}{*}{ Year } & \multirow{2}{*}{$\begin{array}{l}\text { Test } \\
\text { plot }\end{array}$} & \multicolumn{2}{|r|}{ S. caecutiens } & \multicolumn{2}{|r|}{ S. minutus } \\
\hline & & $\begin{array}{l}\text { Trapped*, } \\
\text { Ind. }\end{array}$ & Travelled distances*, m & $\begin{array}{l}\text { Trapped*, } \\
\text { Ind. }\end{array}$ & Travelled distances*, m \\
\hline \multirow[t]{8}{*}{2018} & 1 & 1 & - & 0 & - \\
\hline & 2 & 0 & - & 0 & - \\
\hline & 3 & $3(1)$ & $0(1)$ & 0 & - \\
\hline & 4 & 0 & - & 0 & - \\
\hline & 5 & $2(1)$ & $2900(1)$ & 8 & - \\
\hline & 6 & 5 & - & 0 & - \\
\hline & 7 & 0 & - & 0 & - \\
\hline & 8 & $6(1)$ & $3300(1)$ & 0 & - \\
\hline \multirow[t]{10}{*}{2019} & 1 & 1 & - & 0 & - \\
\hline & 2 & $29(3)$ & $4150(1), 4500(2)$ & 30 & - \\
\hline & 3 & $34(2)$ & $2500(1), 2550(1)$ & $32(1)$ & $2570(1)$ \\
\hline & 4 & $8(2)$ & $750(2)$ & $2(2)$ & $725(1), 750(1)$ \\
\hline & 5 & 0 & - & 0 & - \\
\hline & 6 & $31(1)$ & $80(1)$ & 7 & - \\
\hline & 7 & $26(2)$ & $450(2)$ & $2(2)$ & $475(1), 500(1)$ \\
\hline & 8 & 0 & - & 0 & - \\
\hline & A & 1 & - & 1 & - \\
\hline & $\mathrm{B}$ & $11(1)$ & $0(1)$ & 0 & - \\
\hline
\end{tabular}

* - the number of marked individuals caught at a given point or at a given distance is shown in brackets

Figures 

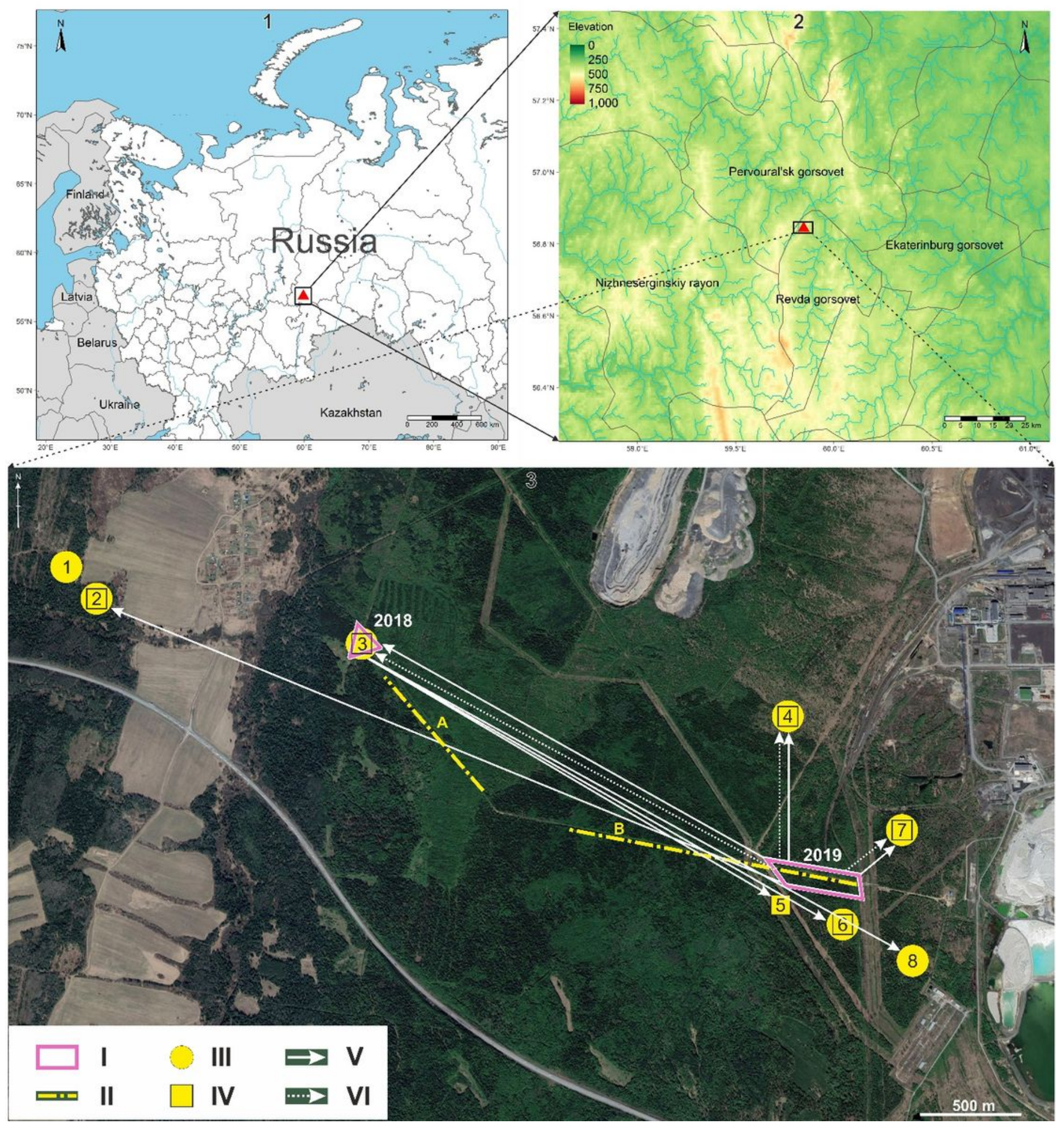

Figure 1

Spatial design of the experiment and the revealed movement directions of $\mathrm{S}$. caecutiens and S. minutus. I - marking plots in 2018-2019; II, A, B - snap trap transects; III - snap and live trap test plots; IV - pitfall trap plots; V - observed movements of S. caecutiens; VI - observed movements of S. minutus. Map source: Google Earth 